\title{
DISPARITIES IN TOURISM DEMAND OF UNESEO DESTINATIONS
}

\author{
Stanislava Pachrová ${ }^{1 *}$, Eva Janoušková ${ }^{2}$ and Jitka Ryšková ${ }^{3}$ \\ ${ }^{1223)}$ College of Polytechnics Jihlava, Jihlava, Czech Republic
}

Please cite this article as:

Pachrová, S., Janoušková, E. and Ryšková, J., 2018.

Disparities in tourism demand of UNESCO destinations.

Amfiteatru Economic, 20(Special No. 12), pp. 1040-1054.

\section{Article History}

Received: 28 August 2018

Revised: 27 September 2018

Accepted: 19 October 2018

DOI: $10.24818 / \mathrm{EA} / 2018 / \mathrm{S} 12 / 1040$

\begin{abstract}
This paper clarifies disparities in tourism demand of some chosen UNESCO destinations in the Czech Republic, which is located in Central Europe. The Czech Republic, despite its relatively small area, is an important destination for cultural tourism - a large number of unique cultural and other historic monuments are located on its territory. Twelve of those historic monuments are inscribed on the UNESCO World Heritage List, including the Czech capital, the city of Prague. As capitals are usually very different from the regions as far as tourism demand is concerned, another separate study area was chosen for this case - the Vysočina Region located in the middle of the Czech Republic. This region has the most UNESCO World Heritage Sites of all the Czech regions - there are three of them there: Telč, Třebíč and Zelená hora in Žd'ár nad Sázavou. Within the framework of developing a new regional tourism strategy and at the request of the Regional Authority of the Vysočina Region, an extensive marketing survey among visitors to the region was carried out. This research was done by the College of Polytechnics Jihlava in 2014-2015 and within it, various characteristics of tourism demand in all three UNESCO destinations were gathered. The research provided background information for creating visitor profiles of the destinations. Primary data obtained from the questionnaire survey enabled, after being processed by various mathematical and statistical methods, a comparative analysis of the chosen UNESCO destinations in Central Europe in terms of tourism demand. Its results show, e.g. that all surveyed destinations attract mainly one-day visitors, but not all of them regard a visit to unique cultural heritage sites of those destinations as their main reason for travelling there. The research results show not only new visitor profiles of the UNESCO destinations in the smallest statistical unit (the municipality), but they can also be used by destination management for planning customised tourism development strategies. Moreover, the study gives a comprehensive picture of tourism demand, which is important for the regional policy. Finally, the paper can be used as a case study for sustainable development of tourism in other UNESCO destinations.
\end{abstract}

Keywords: cultural tourism, marketing research, visitor profile, destination management, data analysis, UNESCO, Czech Republic

JEL Classification: L83, M31

*Corresponding author, Stanislava Pachrová - stanislava.pachrova@vspj.cz 


\section{Introduction}

Tourism is currently perceived to be a traditional factor of regional development of many destinations. Destinations purposefully invest in tourism development as they expect an increase in the local economy as well as the living standards of the local population. Primary expectations to be fulfilled, e.g. by inscribing a particular destination on the UNESCO World Heritage List, are sustainable tourism development and the growth of competitiveness of such a destination. Logically, if a destination is inscribed on this prestigious List, its attractiveness to tourists significantly increases. Such an increase of attractiveness is closely connected to a growing number of tourism activities, such as ancillary services provided for visitors, the development of local infrastructure or the increasing employment of locals in services. On the other hand, tourism development also brings negative impacts on destinations. Therefore, professional public began to pursue research of the impact of tourism on a destination before and after its inscription on the UNESCO List.

Research on travel and tourism around the world deals with the question whether the inscription of a destination on the UNESCO World Heritage List changes the demand for the destination in a fundamental way and whether those changes are of a permanent character. So far, these questions have had no clear answers, results of different researches are not unambiguous (see e.g. Buckley, 2004; Cuccia, 2012; Yong Yeu Moy and Phongpanichanan, 2014; Zhang, Fyall and Zheng, 2015; Ribaudo and Figini, 2017), so there is still a need for further investigation, as well as for a debate on this subject. Our study contributes to this literature and gives new research results (based on primary data) about demand in the Czech Republic to the topic which is essential for sustainable development of tourism in the UNESCO destinations.

This paper is to contribute to the issue solved by clarifying disparities in tourism demand of chosen UNESCO destinations in the Czech Republic, a central European country. The Czech Republic, despite its relatively small area, is an important European destination for cultural tourism - a large number of unique cultural and other historic monuments are located on its territory. Twelve of those historic monuments are registered in the UNESCO World Heritage List, including the Czech capital, the city of Prague. As capitals are usually very different from the other regions as far as tourism demand is concerned, another study area was chosen for this case - the Vysočina Region located in the middle of the Czech Republic. This region has got the most UNESCO World Heritage Sites among all Czech regions - three are three of them there: The Historic Centre of Telč, The Pilgrimage Church of St John of Nepomuk at Zelená Hora in Žd'ár nad Sázavou and The Jewish Quarter and St Procopius' Basilica in Třebíč.

Authors did a marketing survey among 630 visitors to the region, so various characteristics of tourism demand in all three UNESCO destinations were gathered. The research provided background information for creating visitor profiles of the destinations. Primary data obtained from the questionnaire survey enabled, after data analysis, a comparative analysis of the chosen UNESCO destinations in Central Europe in terms of tourism demand.

Systematic research on demand for the UNESCO destinations has not been conducted in Central Europe very much so far, and therefore this paper can provide novelty and originality - primary data essential to the issue in question. The data of the individual UNESCO destinations are compared as a part of a comparative analysis, with the date for the whole Vysočina Region and thus this paper can also serve as a practical tool for policy makers or destination management organizations. Finally, this paper can be used as a case study for sustainable development of tourism in other UNESCO destinations because it shows how to apply marketing research in a tourism practice. 
The paper is structured as follows: the next chapter offers a critical review of recent literature, then a brief description of investigated destinations is given. The third chapter highlights two research null hypotheses, the data and the used methodology. The fourth chapter is about main research results and contains a discussion of findings. Final conclusions underline the main results and contribution of the paper.

\section{Literature review}

As stated by Lara and Gemelli (2012, p.143), the UNESCO encourages the identification, protection and also preservation of cultural and natural heritage considered to be of outstanding value to humanity. This is the main mission of the Convention Concerning the Protection of the World Cultural and Natural Heritage from 1972. Since 1978, when the first twelve sites from seven countries of the world were inscribed on the UNESCO World Cultural and Natural Heritage List, more and more sites are being added to the List every year. At present, there are 1,052 sites in 165 states all over the world listed on the UNESCO World Cultural and Natural Heritage List, 818 of which in 146 states are on the UNESCO World Cultural Heritage List. (UNESCO World Heritage Centre, 1992-2017b).

The question whether an inscription of a destination on the UNESCO World Heritage List brings some fundamental changes in the demand for the particular destination and whether those changes will be of a long-lasting nature is dealt with by research on tourism all over the world. For this reason, the following overview of professional literature cannot be exhaustive.

Buckley (2004) published one of the first articles dealing with effects of an inscription of a destination on the UNESCO World Heritage List on tourism demand. He described a positive effect particularly for international tourists. Yang, Lin and Han (2010) and Arita et al. (2011) agree with significant increase of tourism demand, this time among Chinese tourists. Cuccia (2012) had also found a positive effect which could be seen in overnight stays of tourists. Patuelli, Mussoni and Candela (2013), as well as Su and Lin (2014), Remoaldo, Ribeiro and Vareiro (2014), or Robinson (2015) showed in their works a positive effect on tourism demand, too.

On the other hand, some studies describe also negative (e.g. Poria, Reichel and Cohen, 2013), or no significant effects (Yong Yeu Moy and Phongpanichanan, 2014) on tourism demand of the UNESCO destinations. Ribaudo and Figini (2017) did an extensive study on Italian UNESCO destinations, but they also did not prove any consistent trends in the tourism demand of the surveyed destinations.

Another study close to our research subject might be the work by Poria, Butler and Airey (2004) who surveyed the motivation to visit some selected UNESCO destinations in Israel. Tchetchik, Fleischer, and Shoval (2009) carried out a segmentation of visitors to the Old City of Acre (Israel) by using modern high-resolution time-space data recorded by GPS units. Lara and Gemelli (2012) dealt with the conditions which are necessary for responsible tourism in the UNESCO sites in Argentina. Lee, Lee and Lee (2013) described the dynamic changes of the image of the UNESCO destination of Seoul (Republic of Korea) as well as the impact of the overall visitors satisfaction on the image changes of the particular destination. Zhang, Fyall and Zheng (2014) discussed conflicts between heritage and tourism within world heritage sites in China. Neuts et al. (2016) dealt with the investigated segmentation of visitors and their potential economic impact on the model territory of Shiretoko (Japan). Losson (2017) published a critical 
study on how to provide potential visitors with information through the press. It was shown at the example of the first UNESCO monument belonging together to six states - the Andean roadway system Qhapaq Nan. At present, considerable attention is paid to the issue of practical conservation of the UNESCO sites while maintaining all the dimensions of the carrying capacity of the environment in a satisfactory condition - see the case study by Gribaudo, Iacono and Levis (2017) on monitoring an extended cultural heritage area, the centre of Matera (an Italian town that will be a European Capital of Culture in 2019). Systematic research of tourism in the Czech UNESCO destinations in the Vysočina Region has long been conducted by the staff of the Department of Travel and Tourism, the College of Polytechnics Jihlava, see e.g. Janoušková (2012), Pachrová and Janoušková (2013, 2016), Rux et al. (2014), Šedivá Neckářová (2015), Janoušková, Pachrová and Šedivá Neckářová (2015), or Pachrová, Janoušková and Šedivá Neckářová (2017).

\section{The Vysočina Region and its UNESCO destinations}

The Vysočina Region is situated in the central part of the Czech Republic. In total there are slightly over 508,000 inhabitants living in the region (Český statistický úrad, 2017). As stated by Pachrová, Janoušková and Šedivá Neckářová (2017, p.50), almost the entire area of the Vysočina Region has excellent preconditions for the development of tourism and it is sought after by visitors not only for its picturesque harmonious cultural landscape with suitable conditions for sports and recreational activities, but also for a number of well-preserved historic monuments, continuing folk traditions and many cultural and social facilities, such as theatres, galleries and museums.

Cultural heritage of mankind can be described as one of the most important non-renewable primary sources of tourism and acts as the basic motivation-for sightseeing tourism (Pásková, 2014, pp.38-39). The degree of the cultural heritage attractiveness for visitors is influenced especially by its uniqueness and authenticity. For this reason, becoming a UNESCO listed site is perceived worldwide as a symbol of quality demonstrating the compliance with those required characteristics. There are three of the twelve Czech UNESCO World Heritage sites in the Vysočina Region: The Historic Centre of Telč, The Pilgrimage Church of St John of Nepomuk at Zelená Hora in Žd'ár nad Sázavou and The Jewish Quarter with its cemetery, and St Procopius' Basilica in Třebíč.

The town of Telč lies in the south-western part of the Vysočina Region, approximately halfway between Prague and Vienna. Telč is a remarkable cultural and economic centre of the southern part of the region, the importance of services and tourism is becoming more and more important to the economy of Telč and its surrounding area (Pachrová, Janoušková, 2013). The system of ponds around the historic core of the town as well as the Renaissance rebuilding of the castle and burgher houses with gables and arcades gave Telč its unique appearance. Since 1970, the Gothic-Renaissance historic centre of the town has been one of the most valuable Urban Conservation Areas in the Czech Republic and in 1992 the Historic Centre of Telč was inscribed on the UNESCO World Heritage List and both, the individual buildings and the townscape have been preserved there. The Chateau in Telč has long been one of the most important tourist attractions in the Vysočina Region (Janoušková, 2012), in 2015 it ranked third in the Vysočina Region with more than 84,000 visitors (CzechTourism, 2016), in the year 2016 it was visited by more than 93,000 visitors (NIPOS, 2017, p. 33). 
The town of Žd'ár nad Sázavou is situated on the border between Bohemia and Moravia. Its history is connected with the foundation of a Cistercian monastery where an extensive reconstruction was carried out by the architect Jan Blažej Santini Aichel in the $18^{\text {th }}$ century. The Pilgrimage Church of St John of Nepomuk at Zelená Hora, inscribed on the UNESCO World Heritage List in 1994, is Santini's masterpiece. It is a star-shape pilgrimage site and it is an outstanding example of an architectural style that spanned the transition between the Gothic and Baroque. The composition of the property is based on the concept of a perfect central complex using the number 5 , which is a reference to the five stars of the halo of St. John of Nepomuk (UNESCO World Heritage Centre, 1992-2017a). The monastery and Zelená Hora was the fifth most visited tourist destination of the Vysočina Region with 31,000 visitors in the year 2015 (CzechTourism, 2016). The attendance of The Pilgrimage Church of St John of Nepomuk was 36,533 people in 2016 (Zelená hora, 2015).

Třebíč is situated in the south-eastern part of the Vysočina Region. Třebíč was listed as a UNESCO World Heritage Site in 2003 thanks to its ensemble of sights - The Jewish Quarter, The Jewish Cemetery, and St Procopius' Basicila. The UNESCO site is not only of a rare architectural and urban value, but it is also a unique example of harmonious coexistence of Christian and Jewish cultures from the Middle Ages to the $20^{\text {th }}$ century. St Procopius' Basilica was built in the middle of the $13^{\text {th }}$ century in the Romanesque-Gothic Style as a part of the Benedictine monastery. The completely well-preserved ground plan of the Jewish Quarter shows various aspects of life of Jewish community forced to live in a limited space due to political constraints. The Jewish Quarter includes over 120 preserved buildings, such as the Front and Rear Synagogue, the Rabbinate, or a former leather factory. The Jewish Quarter also includes a large cemetery that lies outside the Jewish Quarter. There are approximately 11,000 graves and 3,000 tombstones, the oldest of which dates back to the year 1625 (Třebíč, 2017). The Basilica was the tenth most visited tourist destinations in the Vysočina Region in 2015 (20,000 visitors), the Rear Synagogue in the Jewish Quarter ranked ninth with 25,000 visitors (CzechTourism, 2016). In 2016, the number of visitors to St Procopius' Basilica was at the same level and 3\% lower when it comes to the Rear Synagogue (NIPOS, 2017).

\section{Research methodology}

Within the framework of developing a new regional tourism strategy, at the request of the Regional Authority of the Vysočina Region, an extensive marketing survey amongst visitors to the region was carried out (for more information see Pachrová, Janoušková and Šedivá Neckáŕová, 2017). This research was done by the College of Polytechnics Jihlava in 2014 2015. The research provided background information for creating visitor profiles of all three UNESCO destinations in the Vysočina Region. This paper presents some chosen primary marketing research results, showing the various characteristics of tourism demand in the selected UNESCO destinations.

The partial objectives of the paper are to verify two null hypotheses $\left(\mathrm{H}_{0}\right)$ that should contribute to a professional discussion on the effects of registering a destination on the UNESCO List on visitor demand:

- $\mathrm{H}_{01}$ - The profile of visitors to UNESCO destinations does not significantly differ from the overall visitor profile of the Vysočina Region. 
- $\mathrm{H}_{02}$ - The structure of visitors to UNESCO destinations proves that those destinations are mainly foreign tourism destinations.

UNESCO destination research was conducted by a quantitative survey method using standardized questionnaires. The questionnaire contained 22 questions (17 closed, 3 open and 2 semi-open) and was created in five languages (Czech, English, German, Russian and Polish). The data collection was performed by interviewing visitors in the field at some preselected locations at the individual destinations, the data collected from the respondents was anonymous. The polling areas were selected based on the principle of the tourism intensity. Data collection was systematically conducted from October 2014 to September 2015 in three time periods - see table no. 1. The size of the respondents sample in each location was predetermined by the research developer. The total sample number was 630 respondents $(250$ in Telč, 180 in Třebíč and 200 in Žd'ár nad Sázavou - also referred to only as Žd'ár).

Table no. 1: Number of filled questionnaires in each stage of research

\begin{tabular}{|c|c|c|c|c|}
\hline \multirow[b]{2}{*}{ Destination } & \multicolumn{3}{|c|}{ Research period (number of questionnaires) } & \multirow{2}{*}{$\begin{array}{c}\text { Total number } \\
\text { of } \\
\text { questionnaires }\end{array}$} \\
\hline & $\begin{array}{c}\mathbf{1}^{\text {st }} \text { period } \\
(10 / 14-02 / 15)\end{array}$ & $\begin{array}{c}2^{\text {nd }} \text { period } \\
(03 / 15-06 / 15)\end{array}$ & $\begin{array}{c}\mathbf{3}^{\text {rd }} \text { period } \\
(07 / 15-09 / 15)\end{array}$ & \\
\hline$\overline{\text { Telč }}$ & 100 & 50 & 100 & 250 \\
\hline Třebíč & 50 & 50 & 80 & 180 \\
\hline Žd'ár & 50 & 50 & 100 & 200 \\
\hline
\end{tabular}

As stated by Pachrová and Janoušková (2016, pp.144-145), the questioning was carried out by trained interviewers so that their personal preferences were not transferred into the research results and that the respondents' selection was based on the principle of random sampling. During the period of data collection, the main emphasis was placed on the diversity of the sample and on the highest possible number of foreign visitors. However, at the same time, the selection of respondents should not be one-sided and the interviewed visitors should not form homogeneous groups. The data was collected repeatedly on all weekdays and at different time periods to avoid results distortion by such factors as weather conditions.

For verification of the set null hypotheses attention to the sociodemographic, geographic, psychographic and behavioral structure of visitors was paid. To verify the set $\mathrm{H}_{01}$ null hypothesis and, also to increase the practical applicability of research results for policy makers and destination management organizations, a comparative analysis of the latest research results of UNESCO destinations with the profile of the Vysočina Region visitor will also be carried out. This profile was created by the team of authors, Pachrová, Janoušková and Šedivá Neckářová (2017).

When processing the obtained primary data, mathematical and statistical methods were used. From the methods of scientific work especially, methods of analysis and synthesis were used. Data from the questionnaires were arranged into pivot tables, and for the statistical evaluation and results presentation program Excel and statistical software STATISTICA 12 and 13 were used. Among the evaluated variables in the individual UNESCO destinations, a significant relationship was tested using the Pearson statistics $\chi^{2}$ (Pearson's chi-squared independence test). $\chi^{2}$ expresses the relationship between the observed frequencies that were determined by sorting the data into the pivot tables $\left(\mathrm{n}_{\mathrm{ij}}\right)$ and the frequencies expected in the case of the independence of variables $\left(\mathrm{m}_{\mathrm{ij}}\right)$, where $\mathrm{r}$ represents the number of rows and $\mathrm{s}$ the number of 
columns of the pivot table (Pecáková, 2011 cited in Pachrová, Janoušková and Šedivá Neckářová, 2017, p. 70):

$\mathrm{X}^{2}=\sum_{i}^{r} \sum_{j}^{s} \frac{\left(n_{i j}-m_{i j}\right)^{2}}{m_{i j}}$

For the use of Pearson's chi-squared independence test, it is necessary that the individual results summarized in the pivot table were independent. It means that each element of the sample is included in only one pivot table cell, and it is necessary to accept the condition that a maximum of $20 \%$ of the expected frequencies is less than 5. For Pearson statistics $\chi^{2}$, for completeness, the number of degrees of freedom (df) where:

$d f=(r-1)(s-1)$

Within the research, other null hypotheses that assumed the independence of the two selected characters were set besides $\mathrm{H}_{01}$ and $\mathrm{H}_{02}$. These are, however, stated in the paper only in the case that they were not confirmed and the dependence was found. Based on the chi-squared probability distribution, the so-called p-value, which is the lowest level of significance for which the null hypothesis can be rejected, was found out for the selected null hypotheses. In the case that $p \leq 0.05$ was valid, the null hypothesis was rejected and the validity of the alternative hypothesis was confirmed.

To show the selected relationships in the two-dimensional pivot table, a method of correspondence analysis explaining the value of $\chi^{2}$ was used. According to Hendl (2012 cited in Pachrová, Janoušková and Šedivá Neckárová, 2017, p. 70), a correspondence analysis proves that there is a relationship between variables, further it shows how variables are associated and determines which categories are closest to each other. For graphical representation of the correspondence analysis results, biplots were used to display both column and line points in one chart. The closer the column or line points in the correspondence chart are, the more similar the category profiles for the same variable are.

\section{Results and discussion}

As table no. 2 illustrates, the representation of men and women in the sample files of the individual UNESCO destinations was balanced and corresponded with the data at the regional level. Interestingly, it was found out that the age composition of Telč visitors is significantly different from the other UNESCO destinations and is also different from the regional average. Telč has the significantly lowest percentage of visitors up to 25 years $(9 \%)$, which is half when compared with the Vysočina Region, 10\% less than in Žd'ár and 14\% less than in Třebíč. On the other hand, Třebíč has a significantly lower proportion of visitors over 60 years of age (4\%, which is half when compared with Vysočina Region). Žd'ár nad Sázavou differs from the other destinations in the educational structure of the visitors, where it has the highest share of the least educated visitors - one third of respondents in this destination did not even finish their high school education. 
Table no. 2: Sociodemographic structure of respondents

\begin{tabular}{|c|c|c|c|c|c|}
\hline \multirow{2}{*}{\multicolumn{2}{|c|}{ Respondents characteristics }} & \multicolumn{4}{|c|}{ Destination } \\
\hline & & \multirow{2}{*}{$\begin{array}{c}\begin{array}{c}\text { Telč } \\
(\%)\end{array} \\
54 \\
46\end{array}$} & \multirow{2}{*}{$\begin{array}{c}\begin{array}{c}\text { Třebíč } \\
(\%)\end{array} \\
50 \\
50\end{array}$} & \multirow{2}{*}{$\begin{array}{c}\begin{array}{c}\text { Žd'ár } \\
(\%)\end{array} \\
51 \\
49\end{array}$} & \multirow{2}{*}{$\begin{array}{l}\begin{array}{l}\text { Vysočina Region } \\
(\%)\end{array} \\
51 \\
49\end{array}$} \\
\hline Gender & $\begin{array}{l}\text { Women } \\
\text { Men }\end{array}$ & & & & \\
\hline Age & $\begin{array}{l}\text { Up to } 25 \text { years } \\
26-34 \text { years } \\
35-49 \text { years } \\
50-59 \text { years } \\
60 \text { years and above }\end{array}$ & $\begin{array}{c}9 \\
32 \\
34 \\
16 \\
9\end{array}$ & $\begin{array}{l}23 \\
30 \\
33 \\
10 \\
4\end{array}$ & $\begin{array}{c}19 \\
22 \\
31 \\
19 \\
9\end{array}$ & $\begin{array}{c}18 \\
29 \\
31 \\
14 \\
8\end{array}$ \\
\hline Education & $\begin{array}{l}\text { Without high } \\
\text { school } \\
\text { High school } \\
\text { University/college }\end{array}$ & $\begin{array}{l}15 \\
60 \\
25\end{array}$ & $\begin{array}{l}18 \\
68 \\
14\end{array}$ & $\begin{array}{l}32 \\
45 \\
23\end{array}$ & $\begin{array}{l}19 \\
57 \\
24\end{array}$ \\
\hline
\end{tabular}

In the process of determining the geographical structure of the respondents, it was detected whether the visitors came from abroad, or whether they are residents of the Czech Republic. As shown in table no. 3 , in all surveyed UNESCO destinations domestic visitors are predominant.

Table no. 3: Structure of respondents based on the distance from their residence place to the destination

\begin{tabular}{|c|c|c|c|c|c|}
\hline \multirow{2}{*}{\multicolumn{2}{|c|}{$\begin{array}{l}\text { Distance from residence } \\
\text { place }\end{array}$}} & \multicolumn{4}{|c|}{ Destination } \\
\hline & & $\begin{array}{l}\text { Telč } \\
(\%)\end{array}$ & $\begin{array}{c}\text { Třebíč } \\
(\%)\end{array}$ & $\begin{array}{c}\text { Žd'ár } \\
(\%)\end{array}$ & $\begin{array}{c}\text { Vysočina } \\
\text { Region }(\%)\end{array}$ \\
\hline \multirow{4}{*}{ Domestic } & Up to $20 \mathrm{~km}$ & 8 & 12 & 32 & 26 \\
\hline & $21-50 \mathrm{~km}$ & 17 & 35 & 28 & 24 \\
\hline & $51-100 \mathrm{~km}$ & 14 & 30 & 25 & 21 \\
\hline & Above $100 \mathrm{~km}$ & 26 & 20 & 12 & 22 \\
\hline \multicolumn{2}{|c|}{ From abroad } & 35 & 3 & 3 & 7 \\
\hline
\end{tabular}

The set null hypothesis $\mathrm{H}_{02}$, which assumed that UNESCO destinations are mainly foreign tourism destinations, has not been confirmed and thus the validity of an alternative hypothesis was proven. The surprising finding was that Třebíč and Žd'ár have less than half the proportion of foreign visitors than the Vysočina Region. On the other hand, Telč also significantly differs in the research results, because foreign visitors exceed one third of the total number of respondents there and at the same time this destination shows a significantly lower proportion of visitors from the surrounding area (up to $20 \mathrm{~km}$ ). To Třebíč and Žd'ár the most foreign visitors came from Slovakia, whilst to Telč, most visitors came from Germany and Austria. Based on the research results it can be assumed that as for Telč, the registration of the destination on the UNESCO List markedly influenced the number of visitors from abroad what is a consistent finding with Buckley (2004) results, but as this does not happen in other investigated destinations, this result can not be generalized. It would be very interesting in the follow up research to explain the reasons for more than $30 \%$ of the difference in the relative frequency of foreign visitors to the other UNESCO destinations in the Vysočina Region. 
The psychographic and behavioral structure of visitors to UNESCO destinations compared with the Vysočina Region structure is presented in tables no. 4 - 6. The results of the research show that Telč is significantly different from the other two UNESCO destinations and differs also the most from the total data on visitors from the entire Vysočina Region. More than half of Telč visitors, for example, arrive for sightseeing, while for the other two UNESCO destinations, this motivation is evident for only a quarter of respondents. More than a quarter of visitors come to Žd'ár with the aim of hiking and sports and only $5 \%$ of respondents come for the same reason to Telč (see table no. 4). More than half of the visitors came to Telč for the first time, and approximately half of the visitors have been to Třebíč and Žd'ár for at least a fourth time (see table no. 5). In all destinations the numbers of one-day visitors are dominant (approximately half of the total); in Telč about $40 \%$ of visitors spend one night (or two), which is about $15 \%$ more than in Třebíč and Žd'ár (see table no. 6). If a visitor spends a night in one of the researched destinations, they are most likely to choose a guesthouse in Žd'ár, a three-star or four-star hotel in Třebíč, and in Telč the accommodation will be evenly divided between $2^{*}-4^{*}$ hotels and guesthouses. In all destinations, about $40 \%$ of visitors spend between $200-500 \mathrm{CZK}$ per person per night.

Table no. 4: Main reasons to visit the destination

\begin{tabular}{|l|c|c|c|c|}
\hline \multirow{2}{*}{ Main reason for visit } & \multicolumn{4}{|c|}{ Destination } \\
\cline { 2 - 5 } & $\begin{array}{c}\text { Telč } \\
(\%)\end{array}$ & $\begin{array}{c}\text { Třebíč } \\
(\%)\end{array}$ & $\begin{array}{c}\text { Žd'ár } \\
(\%)\end{array}$ & $\begin{array}{c}\text { Vysočina } \\
\text { Region (\%) }\end{array}$ \\
\hline Sightseeing & $\mathbf{5 5}$ & 27 & 22 & 27 \\
\hline Relaxation & 12 & 15 & 14 & 14 \\
\hline Hiking and sport & 5 & 19 & $\mathbf{2 7}$ & 20 \\
\hline Health & 0 & 1 & 1 & 2 \\
\hline Work & 2 & 6 & 9 & 7 \\
\hline Entertainment & 17 & 10 & 10 & 11 \\
\hline Shopping & 0 & 5 & 3 & 4 \\
\hline $\begin{array}{l}\text { Visit to } \\
\text { relatives/friends }\end{array}$ & 7 & 11 & 11 & 10 \\
\hline Transit & 2 & 6 & 3 & 5 \\
\hline
\end{tabular}

Table no. 5: Structure of respondents according to the frequency of visits to the destination

\begin{tabular}{|l|c|c|c|c|}
\hline \multirow{2}{*}{ Visit frequency } & \multicolumn{4}{|c|}{ Destination } \\
\cline { 2 - 5 } & Telč $(\%)$ & $\begin{array}{c}\text { Třebíč } \\
(\%)\end{array}$ & $\begin{array}{c}\text { Žd'ár } \\
(\%)\end{array}$ & $\begin{array}{c}\text { Vysočina } \\
\text { Region (\%) }\end{array}$ \\
\hline First visit & $\mathbf{5 2}$ & 28 & 23 & 28 \\
\hline Second and third visits & 22 & 32 & 26 & 25 \\
\hline More than three visits & $\mathbf{2 6}$ & 40 & 51 & 47 \\
\hline
\end{tabular}


Table no. 6: Structure of respondents according to length of stay in the destination

\begin{tabular}{|l|c|c|c|c|}
\hline \multirow{2}{*}{ Length of stay } & \multicolumn{4}{|c|}{ Destination } \\
\cline { 2 - 5 } & Telč $(\%)$ & $\begin{array}{c}\text { Třebíč } \\
(\%)\end{array}$ & $\begin{array}{c}\text { Žd'ár } \\
(\%)\end{array}$ & $\begin{array}{c}\text { Vysočina } \\
\text { Region (\%) }\end{array}$ \\
\hline $\begin{array}{l}\text { 1 day (without } \\
\text { accommodation) }\end{array}$ & $\mathbf{4 2}$ & 56 & 58 & 54 \\
\hline 1 - 2 nights & $\mathbf{4 0}$ & 27 & 22 & 27 \\
\hline $3-7$ nights & 15 & 15 & 11 & 12 \\
\hline 8 and more nights & 3 & 2 & 9 & 7 \\
\hline
\end{tabular}

As it is clear from the above stated research results, the set null hypothesis $\mathrm{H}_{01}$ which supposed that the profile of the UNESCO destinations visitors does not significantly differ from the overall visitor profile of the Vysočina Region has not been confirmed and thus its alternative hypothesis is valid.

Not only are there differences in demand between UNESCO destinations and the rest of the Vysočina Region, but UNESCO destinations differ significantly also among themselves. Based on the research results, therefore, it is not possible to clearly prove that registering a destination on the UNESCO List will affect the demand in each destination in the same way. This result conforms with findings of Ribaudo and Figini (2017) who also stated that there are no clear-cut conclusions of UNESCO destinations demand in Italy after their listing, because destination findings are different. On the other hand, our findings differ from researches that found only positive effect on tourism demand (Cuccia, 2012; Patuelli, Mussoni and Candela, 2013; Su and Lin, 2014; Robinson, 2015). Finally, we can also differ from research results with "no effect" findings - e.g. Yong Yeu Moy and Phongpanichanan (2014), or even from studies with only negative results (Poria, Reichel and Cohen, 2013).

Further there are stated examples of interesting research results, in which the Pearson statistics $\chi^{2}$ or the method of correspondence analysis were used.

The null hypothesis that the supposed nonexistence of the dependence of the respondents' resident distance on the frequency of visiting UNESCO destination of Telč was checked out by statistical processing. The result of processing the data by Pearson's chi-squared test shows the value of the test statistic $\chi^{2}=141.0154$ and the $p$-value of 0.0000 , thus it is clear that for the destination, the null hypothesis must be rejected at a $5 \%$ significance level. A confirmed alternative hypothesis states that the distance of a visitor residence to the UNESCO destination varies depending on the frequency of visits to the given destination. Research results also show that almost $60 \%$ of Telč visitors who come to this destination for the first time are from abroad and in contrast almost $70 \%$ of visitors who return to the destination repeatedly, come from nearby surroundings (up to $50 \mathrm{~km}$ ).

Statistical data processing at a null hypothesis assuming the independence of the reason for visiting the UNESCO destination on the frequency of destination visits showed, for example in Žd'ár nad Sázavou, a significant dependence, when $\chi^{2}=56.28111$ and $p=0.0000$. The null hypothesis was rejected at a $5 \%$ significance level, as shown in table no. 7 , the reason for visiting the UNESCO destination (Žd'ár) varies noticeably according to the frequency of the destination visits. 
Table no. 7: Reason for visiting Žd'ár nad Sázavou in dependence on frequency of visits to the destination

\begin{tabular}{|c|c|c|c|c|c|}
\hline \multirow[b]{2}{*}{ Reason for visit } & \multirow[b]{2}{*}{ Frequency } & \multicolumn{3}{|c|}{ Visit frequency } & \multirow[b]{2}{*}{ Total } \\
\hline & & $1^{\text {st }}$ visit & $\begin{array}{l}2^{\text {nd }}-3^{\text {rd }} \\
\text { visits }\end{array}$ & $\begin{array}{l}4^{\text {th }} \text { and } \\
\text { further } \\
\text { visits }\end{array}$ & \\
\hline \multirow{2}{*}{ Sightseeing } & A & 23 & 12 & 10 & \multirow{2}{*}{45} \\
\hline & $\mathrm{S}$ & $48.94 \%$ & $23.53 \%$ & $9.80 \%$ & \\
\hline \multirow{2}{*}{ Relaxation } & $\mathrm{A}$ & 8 & 11 & 9 & \multirow{2}{*}{28} \\
\hline & $\mathrm{S}$ & $17.02 \%$ & $21.57 \%$ & $8.82 \%$ & \\
\hline \multirow{2}{*}{ Hiking and sport } & A & 7 & 18 & 30 & \multirow{2}{*}{55} \\
\hline & $\mathrm{S}$ & $14.89 \%$ & $35.29 \%$ & $29.41 \%$ & \\
\hline \multirow{2}{*}{ Health } & A & 0 & 0 & 1 & \multirow{2}{*}{1} \\
\hline & $S$ & $0.00 \%$ & $0.00 \%$ & $0.98 \%$ & \\
\hline \multirow{2}{*}{ Work } & $\mathrm{A}$ & 1 & 1 & 16 & \multirow{2}{*}{18} \\
\hline & $\mathrm{S}$ & $2.13 \%$ & $1.96 \%$ & $15.69 \%$ & \\
\hline \multirow{2}{*}{ Entertainment } & $\mathrm{A}$ & 4 & 3 & 13 & \multirow{2}{*}{20} \\
\hline & $\mathrm{S}$ & $8.51 \%$ & $5.88 \%$ & $12.75 \%$ & \\
\hline \multirow{2}{*}{ Shopping } & $\mathrm{A}$ & 0 & 0 & 6 & \multirow{2}{*}{6} \\
\hline & $\mathrm{S}$ & $0.00 \%$ & $0.00 \%$ & $5.88 \%$ & \\
\hline \multirow{2}{*}{$\begin{array}{l}\text { Visit to } \\
\text { relatives/friends }\end{array}$} & $\mathrm{A}$ & 1 & 5 & 15 & \multirow{2}{*}{21} \\
\hline & $S$ & $2.13 \%$ & $9.80 \%$ & $14.71 \%$ & \\
\hline \multirow{2}{*}{ Transit } & $\mathrm{A}$ & 3 & 1 & 2 & \multirow{2}{*}{6} \\
\hline & $S$ & $6.38 \%$ & $1.96 \%$ & $1.96 \%$ & \\
\hline \multirow{3}{*}{ Total } & A & 47 & 51 & 102 & 200 \\
\hline & $\mathrm{R}$ & $23.50 \%$ & $25.50 \%$ & $51.00 \%$ & $100.00 \%$ \\
\hline & $\mathrm{S}$ & $100 \%$ & $100 \%$ & $100 \%$ & - \\
\hline \multirow[t]{2}{*}{$\begin{array}{l}\text { Pearson chi-squared } \\
\text { test }\end{array}$} & \multicolumn{2}{|c|}{$\begin{array}{l}\text { Pearson } \\
\text { chi-square }\end{array}$} & $\begin{array}{l}\text { Number of } \\
\text { degrees of } \\
\text { freedom }\end{array}$ & \multicolumn{2}{|c|}{ p-value } \\
\hline & \multicolumn{2}{|c|}{$\chi^{2}=56.28111$} & $\mathrm{df}=16$ & \multicolumn{2}{|c|}{$p=0.0000$} \\
\hline
\end{tabular}

Notes: A - absolute frequency, $S$ - column relative frequency, $R$ - relative frequency

From the correspondence analysis that was examining the dependence of the reason for the visits to Žd'ár nad Sázavou on the frequency of visits, it follows that the first visit to the destination is most logically focused on the destination exploring (see figure no. 1). During the next visits, the significance of relaxation and hiking/sport as the reason for the visit increases. The repeated visits then most often relate to entertainment, visiting relatives and friends, work reasons or again to hiking and sports, repeated visits are not influenced by the UNESCO status at all. 


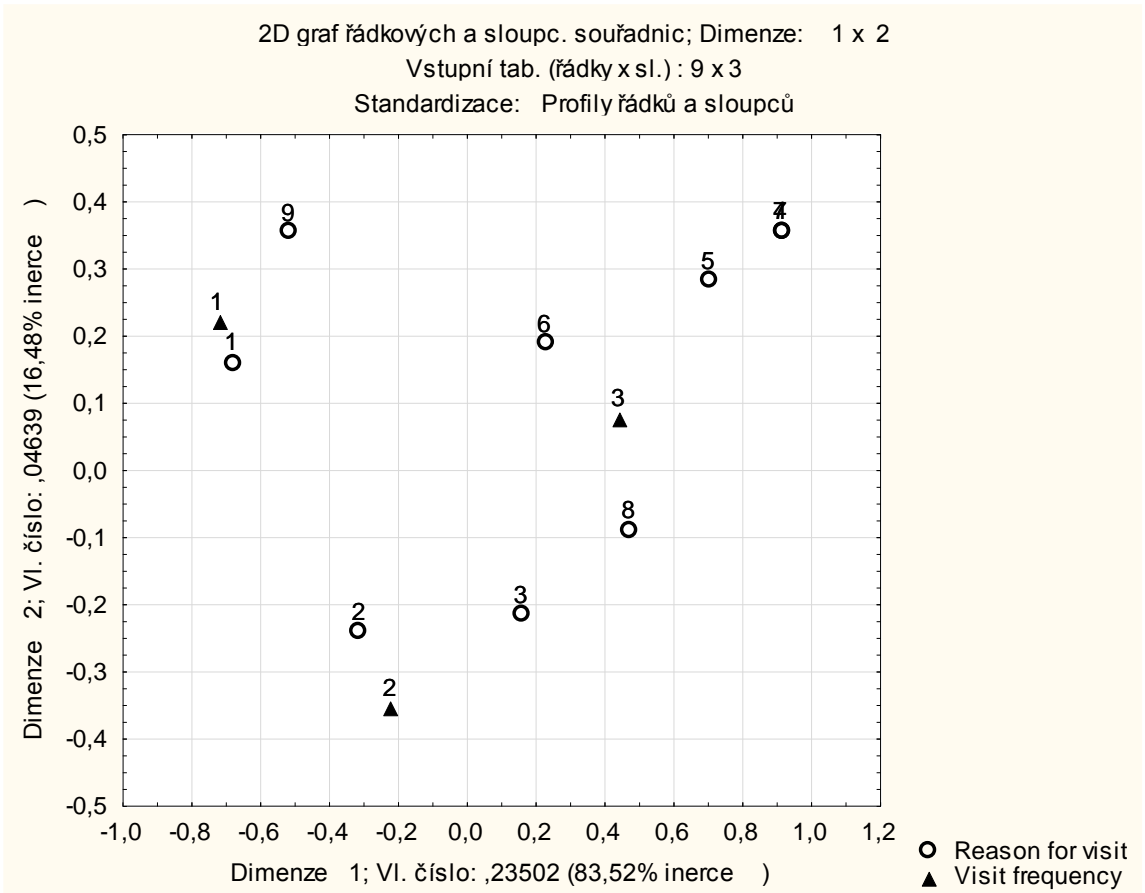

Figure no. 1: The correspondence analysis - the dependence of the reason for the visits to Žd'ár nad Sázavou to the frequency of visits

Notes: Reason for visit: 1 - Sightseeing, 2 - Relaxation, 3 - Hiking and sport, 4 - Health, 5 - Work, 6 Entertainment, 7 - Shopping, 8 - Visit to relatives/friends, 9 - Transit; Visit frequency: 1 - First visit, 2 - Second and third visits, 3 - Fourth and further visits

\section{Conclusions}

Destinations all over the world intentionally support the development of tourism while expecting the related development of the local economy as well as a growth in the living standard of the population. The required sustainable tourism development is a primary expectation and the destinations hope it will be fulfilled by their inscription on the UNESCO World Heritage List. This paper is to contribute to the issue solving whether becoming a UNESCO listed site can change the demand for the destination in a fundamental way by clarifying disparities in the tourism demand of the three UNESCO destinations in the Czech Republic (Telč, Třebíč a Žd'ár nad Sázavou).

There was a primary marketing survey amongst visitors to these destinations carried out in 2014 - 2015. Various characteristics of tourism demand in all three UNESCO destinations mentioned above were gathered. Primary data obtained from the questionnaire survey enabled, after being processed by various mathematical and statistical methods, a comparative analysis of the chosen UNESCO destinations in Central Europe in terms of tourism demand. 
Its results show, e.g. that all the surveyed UNESCO destinations attract mainly one-day visitors, but not all of them regard a visit to unique cultural heritage sites of those destinations as the main reason for travelling there. In all of the chosen destinations a visitor spends 200 -500 CZK per person per day. More than half of the visitors to Telč are first-time visitors. When it comes to Třebíč and Žd'ár, approximately half of their visitors have been there at least for the fourth time. The differences between the destinations are also regarding the distances from which their visitors arrive - almost two thirds of the visitors to Telč come from a distance of more than $100 \mathrm{~km}$ (or from abroad), the visitors arrive in Žd'ár mostly from the nearby area (up to $50 \mathrm{~km}$ ) and in Třebíč from a distance of 21-100 km.

The set null hypothesis $\mathrm{H}_{01}$ suggesting that the profile of visitors to UNESCO destinations does not significantly differ from the overall profile of visitors to the Vysočina Region, has not been confirmed. This research result proves that an inscription of a destination on the UNESCO List differentiate it markedly from other geographically nearby destinations. On the other hand, individual UNESCO destinations differ substantially from one the other in some characteristics (most of which were shown in Telč). The results of this research are not sufficient to prove unequivocally that the inclusion of a destination on the UNESCO List will affect the demand for tourism in the inscribed destination in the same way. It would be interesting to start further research about causalities between demand and supply in the UNESCO destinations after the listing and to find general key factors for the destination success. It is also unclear if there is any impact of the number of listed sites in one area, or listed destinations in one country, on the tourism demand. It can just be estimated that the quality and intensity of a destination promotion and tourism policies influence tourism demand more than the listing itself (Cuccia, 2012).

The set null hypothesis H02 assuming that UNESCO destinations are mostly foreign tourism destinations, has not been confirmed either. The fact that Třebíč and Žd'ár have more than half the proportion of foreign visitors than the Vysočina Region (only 3\% of the total number of their visitors arrived from abroad) was a surprising finding. On the other hand, the rate of foreign visitors to Telč exceeds one third of the total number of respondents. Thus, the inscription of a destination on the UNESCO List does not influence the growth of the number of foreign visitors to the destination unequivocally. Listing might have a different impact on domestic and foreign demand within various segments, so this could be another interesting research avenue for the future.

The research results can be used by destination management for planning customised tourism development strategies. Even if the main research limits are impossible to investigate all visitors to the chosen destinations and possible subjective influence of researches in the field, the chosen research methodology enables us to give a trustworthy picture of tourism demand on the local level of the out of the capital UNESCO destinations in the Czech Republic.

Moreover, the study gives a comprehensive picture of tourism demand, which is important for the regional policy. It would be advisable to continue to carry out this survey by systematic data collecting and by their continual evaluation in order to compile data time series and consequently interpret real changes on the demand for tourism, as well as to start collecting and evaluating data following the same methodology in more UNESCO destinations, so making a comparison of tourism demand among the UNESCO destinations in different countries would be possible.

This paper was written within the framework of an internal grant provided by the College of Polytechnics Jihlava, Analyses of Regional Disparities in Tourism (č. 1170/4/178). 


\section{References}

Arita, S., Edmonds, Ch., La Croix, S. and Mak, J., 2011. Impact of Approved Destination Status on Chinese travel abroad: an econometric analysis. Tourism Economics, 17(5), pp.983-996.

Buckley, R., 2004. The Effects of World Heritage Listing on Tourism to Australian National Parks. Journal of Sustainable Tourism, 12(1), pp.70-84.

Cuccia, T., 2012. Is It Worth Being Inscribed in the World Heritage List? A Case study of „The Baroque Cities in Val di Noto” (Sicily). Rivista Italiana di Economia Demografia e Statistica, LXVI(2), pp. 169-190.

CzechTourism, 2016. Nejnavštěvovanějšś turistické cíle roku 2015: Návštěvnost turistických cíli̊ po krajich. [online] Available at: <http://www.czechtourism.cz/pro-media/tiskovezpravy/nejnavstevovanejsi-turisticke-cile-roku-2015/> [Accessed 5 July 2017].

Český statistický úřad, 2017. Krajská správa ČSÚ v Jihlavě: Nejnovějši údaje o kraji. [online] Available at: 〈https://www.czso.cz/csu/xj> [Accessed 1 July 2017].

Gribaudo, M., Iacono, M. and Levis, A.H., 2017. An IoT-based monitoring approach for cultural heritage sites: The Matera case. Concurrency and Computation-Practice \& Experience, 29(11), article number: e4153.

Janoušková, E., 2012. Rozvoj cestovního ruchu v mikroregionu Telčsko. Geografické informácie, 16(1), pp.142-151.

Janoušková, E., Pachrová, S. and Šedivá Neckářová, A., 2016. Vývoj profilu návštěvníka Telče - města UNESCO. Logos Polytechnikos, 7(3), pp.197-215.

Lara, A.L. and Gemelli, A., 2012. Cultural Heritage: World Heritage Sites and Responsible Tourism in Argentina. In: D. Leslie, ed. 2012. Responsible tourism: concepts, theory and practice. Wallingford (Oxfordshire, UK): CABI, pp.142-153.

Lee, B., Lee, Ch. and Lee, J., 2014. Dynamic Nature of Destination Image and Influence of Tourist Overall Satisfaction on Image Modification. Journal of Travel Research, 53(2), pp.239-251.

Losson, P., 2017. The inscription of Qhapaq Nan on UNESCO's World Heritage List: a comparative perspective from the daily press in six Latin American countries. International Journal of Heritage Studies, 23(6), pp.521-537.

Neuts, B., Romao, J., Nijkamp, P. and Shikida, A., 2016. Market segmentation and their potential economic impact in an ecotourism destination: An applied modelling study on Hokkaido, Japan. Tourism Economics, 22(4), pp.793-808.

NIPOS, 2017. Návštěvnost památek v krajích Č́R v roce 2014 - 2016. [pdf] Praha: NIPOS. Available at: <http://www.nipos-mk.cz/wp content/uploads/2013/05/PAMATKY navstevnost_2016.pdf> [Accessed 23 June 2017].

Pachrová, S. and Janoušková, E., 2013. The Town of Telč - A Unique Tourism Product. In: J. Wyrzykowski and J. Marak, eds. 2013. Tourism Role in the Regional Economy: Regional Tourism Product - Theory and Practice. vol. IV. Wroclaw: University of Business in Wroclaw, pp.482-504.

Pachrová, S. and Janoušková, E., 2016. Marketing Research of Visitors in the Region of Vysočina. In: J. Wyrzykowski, J. Marak and S. Toczek-Werner, eds. 2016. Tourism Role in the Regional Economy: Cultural Tourism as a Branded Tourism Product of Cities, Towns and Regions. Theoretical Framework and European Examples. vol. VI. Wroclaw: University of Business in Wroclaw, pp.136-153. 
Pachrová, S., Janoušková, E. and Šedivá Neckářová, A., 2017. Marketingový výzkum návštěvnosti - významný nátroj destinačního managementu. Příklad Kraje Vysočina. Brno: CERM.

Pásková, M., 2014. Udržitelnost cestovního ruchu. $3^{\text {rd }}$ ed. Hradec Králové: Gaudeamus.

Patuelli, R., Mussoni, M. and Candela, G., 2013. The Effects of World Heritage Sites on Domestic Tourism: A Spatial Interaction Model for Italy. Journal of Geographical Systems, 15(3), pp.369-402.

Poria, Y., Reichel, A. and Cohen, R., 2013. Tourist Perceptions of World Heritage Sites and Its Designation. Tourism Management, 35, pp.272-274.

Poria, Y., Butler, R. and Airey, D., 2004. Links between Tourists, Heritage, and Reasons for Visiting Heritage Sites. Journal of Travel Research, 43(1), pp.19-28.

Remoaldo, P.C., Ribeiro, J.C. and Vareiro, L., 2014. Tourists` perception of world heritage destinations: The case of Guimaraes (Portugal). Tourism and Hospitality Research, 14(4), pp.206-218.

Ribaudo, G. and Figini, P., 2017. The Puzzle of Tourism Demand at Destinations Hosting UNESCO World Heritage Sites: An Analysis of Tourism Flows for Italy. Journal of Travel Research, 56(4), pp.521-542.

Robinson, K., 2015. World heritage listed sites - Does it attract tourists? A study of factors influencing Norwegian tourist's intention to visit UNESCO's world heritage listed sites. Master thesis. University of Nordland.

Su, Y.W. and Lin, H.L., 2014. Analysis of International Tourist Arrivals Worldwide: The Role of World Heritage Sites. Tourism Management, 40, pp.46-58.

Šedivá Neckářová, A., 2015. Př́stupnost turistických atraktivit měst Jihlavy a Třebíče osobám s tělesným postižením. In: Slezská univerzita v Opavě, VIII. Mezinárodní vědecká konference doktorandů a mladých vědeckých pracovníků. Karviná, 5 November 2015. Karviná: SU OPF v Karviné.

Tchetchik, A., Fleischer, A. and Shoval, N., 2009. Segmentation of Visitors to a Heritage Site Using High-resolution Time-space Data. Journal of Travel Research, 48(2), pp.216-229.

Třebíč, 2017. Třebič - město památek UNESCO. [online] Available at: <http://www.trebic. cz/trebic-mesto-pamatek-unesco/ms-30090/p1=30090> [Accessed 7 July 2017].

UNESCO World Heritage Centre, 1992-2017a. Pilgrimage Church of St John of Nepomuk at Zelená Hora. [online] Available at: <http://whc.unesco.org/en/list/690> [Accessed 6 July 2017].

UNESCO World Heritage Centre, 1992-2017b. World Heritage List. [online] Available at: <http://whc.unesco.org/?cid=31\&l=en\&order=year\&mode=list> [Accessed 7 July 2017].

Yang, C.H., Lin, H.L. and Han, C.C., 2010. Analysis of international tourist arrivals in China: The role of world heritage sites. Tourism Management, 31(6), pp.827-837.

Yong Yeu Moy, L. and Phongpanichanan, C., 2014. Does the Status of a UNESCO World Heritage City Make a Destination More Attractive to Mainland Chinese Tourists? A Preliminary Study of Melaka. Procedia - Social and Behavioral Sciences, 144, pp.208-289.

Zelená hora, 2015. Zelená hora: Poutní kostel sv. Jana Nepomuckého na Zelené hoře: Návštěvnost v roce 2016. [online] Available at: <http://www.zelena-hora.cz/cz/news/ navstevnost-v-roce-2016-99> [Accessed 7 July 2017].

Zhang, C., Fyall, A. and Zheng, Y., 2015. Heritage and Tourism Conflict within World Heritage Sites in China: A Longitudinal Survey. Current Issues in Tourism, 18(2), pp.110-136. 